\title{
Original Documents.Schedule of a Parcel of the Lands of Henry Duke of Suffolk, Within the Manor of Lutterworth, Farmed Out to Various Tenants at a Specified Rental
}

\section{Geo T. Clark}

To cite this article: Geo T. Clark (1891) Original Documents.Schedule of a Parcel of the Lands of Henry Duke of Suffolk, Within the Manor of Lutterworth, Farmed Out to Various Tenants at a Specified Rental, Archaeological Journal, 48:1, 190-192, DOI: 10.1080/00665983.1891.10852490

To link to this article: http://dx.doi.org/10.1080/00665983.1891.10852490

\section{曲 Published online: 15 Jul 2014.}

Submit your article to this journal ๘ 


\section{Original Doruments.}

\section{SCHEDULE OF A PAROEL OF THE LANDS OF HENRY DUKE OF SUFFOLK, WITEIN THE MANOR OF LUTTER- WORTE, FARMED OUT TO VARIOUS TENAN'TS AT A SPECIFIED RENTAL.}

\section{Communicated by GEO T. CLARK}

Henry Grey, Duke of Suffolk, Baron Ferrers of Groby and K.G., was created Duke of Suffolk in 1551, was attainted and beheaded in 1554. He was the father of Lady Jane Grey. He represented a family long connected with Lutterworth, Lords of the Manor, patrons of the Church, and of the Hospital of S. John the Baptist.

The manor seems to have been held by Bertram de Verdon in 1086, under a certain Maino, who held it in capite by the tenure of Castle. guard at the castle of Northampton. His descendant Nicholas de Verdon, held both the manor and the advowson, and seems to have founded the hospital in the reign of King John, although the endowment with seven virgates or yard lands was the work of Rohesia, daughter and heiress of Nicholas, in conjunction with Theobald, her son. Rohesia had married Theobald le Buttiler from Ireland, and inherited Newbold-Verdon, Lutterworth, Bittersby, Cottesbach, and Cossington; she being a great heiress her son adopted her surname. He probably re-built the Chancel of Lutterworth Church, the gabe end of which bore, and probably still bears, the arms of Verdon upon a stone escutcheon. Theobald left daughters only, one of whom, Isabel, inherited the manor, advowson, and patronage of the hospital of Lutterworth, and married Henry Baron Ferrers of Groby. Their daughter and heiress, Elizabeth Ferrers, married Edward Grey, of the house of Grey de Ruthyn. There were, however, other wives and other children whose interests intervened; but eventually Edward Grey, who died 1457, was allowed to be Baron Ferrers of Groby by 'the courtesy,' and the Barony descended with Lutterworth to his great grandson, the Duke of Suffollk, who was also Lord of the Manor of Lutterworth, and patron of the Church and of the Hospital of St. John.

On the Duke's attainder the estates vested in the Crown, still patrons of the Church. The manor was sold to Basil Feilding and is held by his descendants, the Earls of Denbigh, and the hospital was dissolved, being valued 37 Henry VIII. at $£ 26$ 9s. 5 d. $p^{\mathbf{r}} a^{\text {nn }} \cdot A$ 
local spring is still known as St. John's Well. The Hospital stood on the River Swift abutting upon Misterton, into which estate its site, called "The Spital," has been incorporated.

In his History of Leicestershire, Nichols gives a very copious account of Lutterworth. Pace the author of Marmion, it does not appear that any of that family were connected with Lutterworth.

\section{Paroelda possessionum Henrici nuper Ducis Stfrolcie Attingti.}

\section{Comitates}

LEICESTRIE.

CerTa TERRE ET TENEMENTA IN LUTTERWORTH PARCELLA MLNERI DE LUTTERWOR TH PREDICTI

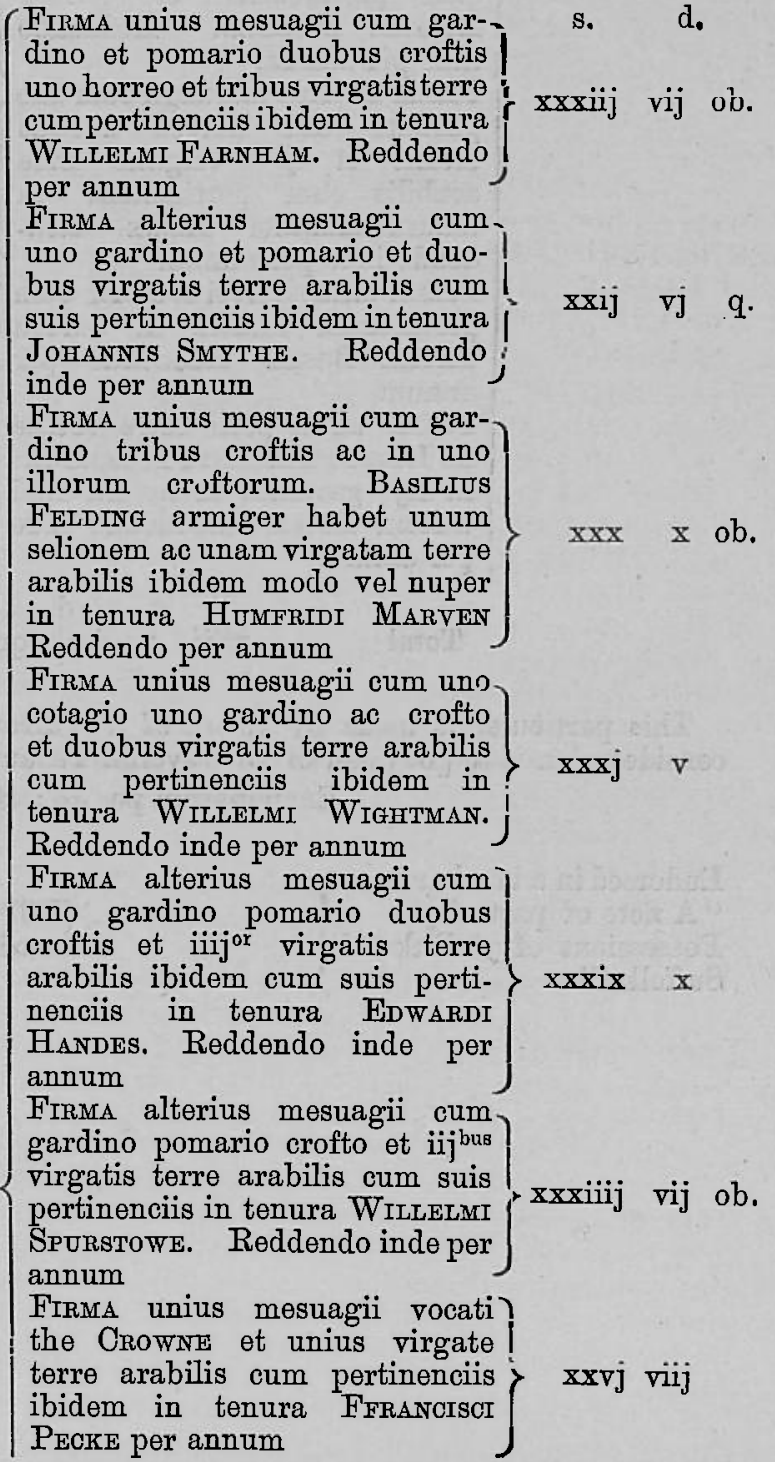




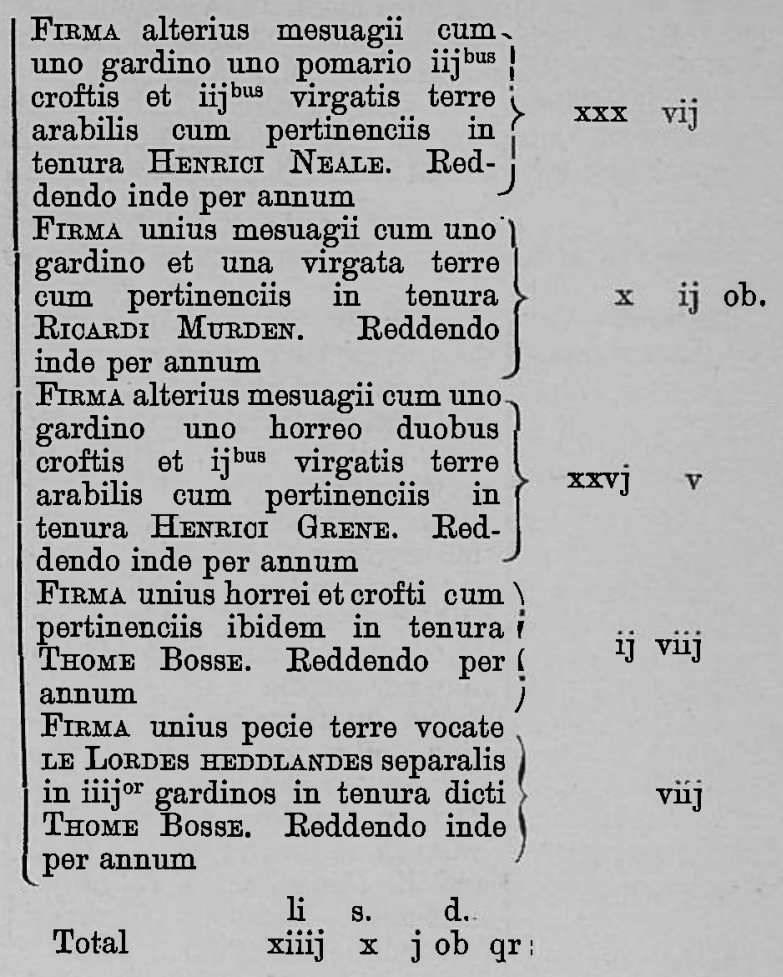

This particuler is made by vertue of a Warraunte for a lease and consideracion is to [be] had of the severall Tenauntes.

Examinatum per Jo: SwIFTE Auditorem.

Endorsed in a late hand :

"A note of part of $\mathrm{y}^{\mathrm{B}}$

Wills CoтtoN

Possessions of $y^{\circ}$ Duke of i xiiiis iijd $\mathrm{ob}: \mathrm{q}^{2}$ : Suffolke." 